\title{
ANALISIS PERBANDINGAN PENGARUH VARIABEL MAKRO EKONOMI TERHADAP STABILITAS BANK SYARIAH DAN BANK KONVENSIONAL DI INDONESIA PERIODE TAHUN 2010-20171
}

\author{
Fajar Fairuzy Sadrinata \\ Departemen Ekonomi Syariah-Fakultas Ekonomi dan Bisnis-Universitas Airlangga \\ Email: Fajar.Fairuzy-13@feb.unair.ac.id \\ Lina Nugraha Rani \\ Departemen Ekonomi Syariah-Fakultas Ekonomi dan Bisnis-Universitas Airlangga \\ Email: Nugraha.rani@feb.unair.ac.id
}

\begin{abstract}
:
The research aims to identify and analyze the partial and simultaneous influence of macroeconomic variables consisting of inflation, GDP, balance of payments, and Bl interest rates on the stability of Sharia banks and conventional banks in Indonesia. The research also aims to analyse the differences in macroeconomic variables to influence the stability of banking between sharia banks and conventional banks in Indonesia. The research was based on comparisons of the influence of stability between sharia banks and conventional banks on the macroeconomic variables investigated. The population in this research is sharia Bank and conventional Bank in Indonesia issued by OJK, sharia Bank statistics and conventional Bank. The analytical techniques used are statistical analyses. The analysis of data in this study uses two phases, namely descriptive statistics and inferential statistics.
\end{abstract}

Keywords: inflation, GDP, payment balance, BI interest rates

\section{PENDAHULUAN}

Menciptakan struktur perbankan domestik yang sehat merupakan tantangan bagi pemerintah dalam hal ini pemangku kebijakan moneter Bank Indonesia (BI) dan Otoritas Jasa Keuangan (OJK) sebagai pengawas perbankan. Sistem perbankan Indonesia menganut sistem perbankan ganda (Dual System Banking)yaitu perbankan syariah dan konvensional. Hal ini jelas merupakan tantangan tersendiri bagi OJK untuk mengatur serta mengawasi sistem perbankan yang ada di Indonesia sesuai dengan Undang-Undang No. 7 Tahun 1992 yang direvisi menjadi Undang-Undang No. 10 Tahun 1998 dan undang-undang yang mengatur khusus tentang perbankan syariah yaitu Undang-Undang No. 21 tahun 2008.

Untuk mewujudkan kesejahteraan masyarakat Indonesia berdasarkan Pancasila dan Undang-Undang Dasar Negara Republik Indonesia Tahun 1945 dan mendukung perekonomian nasional melalui pelaksanaan demokrasi ekonomi dengan prinsip kebersamaan, efisiensi berkeadilan, berkelanjutan, berwawasan lingkungan, kemandirian, serta dengan menjaga keseimbangan kemajuan dan kesatuan ekonomi nasional, diperlukan stabilitas sistem keuangan yang kokoh. Pasal 1 ayat (1) Undang-Undang Republik Indonesia Nomor 9 Tahun 2016 tentang Pencegahan dan Penanganan Krisis Sistem Kevangan dijelaskan bahwa Stabilitas

\footnotetext{
${ }^{1}$ Jurnal ini merupakan bagian dari skripsi dari Fajar Fairuzy Sadrinata, NIM: 041311433064 , yang diuji pada tanggal 16 Juli 2019.
} 
Sadrinata, et al/Jurnal Ekonomi Syariah Teori dan Terapan Vol. 6 No. 10 Oktober 2019: 2095-2109; ANALISIS PERBANDINGAN PENGARUH VARIABEL MAKRO EKONOMI TERHADAP STABILITAS BANK SYARIAH DAN BANK KONVENSIONAL DI INDONESIA PERIODE TAHUN 2010-2017

Sistem Keuangan adalah kondisi Sistem Kevangan yang berfungsi efektif dan efisien serta mampu bertahan dari gejolak yang bersumber dari dalam negeri dan luar negeri.

Bank syariah dilihat dari segi prinsip kerjanya memiliki perbedaan yang mendasar dibandingkan dengan bank konvensional. Bank konvensional menggunakan sistem bunga (riba) sedangkan bank syariah menggunakan sistem bagi hasil yang mengedepankan hubungan kepercayaan antara pihak bank dan nasabah. Pasal 1 ayat (1) Undang-undang No. 21 Tahun 2008 tentang Perbankan Syariah disebutkan bahwa Perbankan Syariah adalah segala sesuatu yang menyangkut tentang Bank Syariah dan Unit Usaha Syariah, mencakup kelembagaan, kegiatan usaha, serta cara dan proses dalam melaksanakan kegiatan usahanya.

Menurut Zainudin (2010:1) bank syariah biasa disebut Islamic banking atau interest free banking, yaitu suatu sistem perbankan dalam pelaksanaan operasionalnya tidak menggunakan sistem bunga (riba), spekulasi (gharar), dan ketidakpastian atau ketidakjelasan (maisir). Di dalam Al-Quran dijelaskan secara tegas bahwa riba merupakan suatu hal yang haram. Hal ini dijelaskan pada surat AlImron ayat 130 :

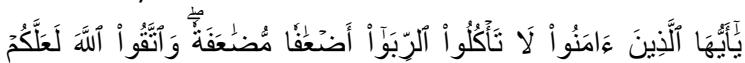

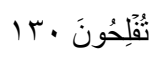

Yā ayyuhallażina āmanū lā ta'kulur-ribā aḍ' āfammuḍā'afataw wattaqullāha la 'allakum tuflihụ̄n.

"Hai orang-orang yang beriman, janganlah kamu memakan riba dengan berlipat ganda dan bertakwalah kamu kepada Allah supaya kamu mendapat keberuntungan (Al-Qur'an kementrian agama RI, 2016:66)".

Menurut Shihab (2010) riba itu sendiri dalam pengertian bahasa artinya adalah bertambah/penambahan. Oleh karena itu ketika turun bahwa riba itu haram, orang-orang musyrik berkata "jual beli itu sama saja dengan riba karena pada hakikatnya jual beli juga ada penambahan keuntungan" tetapi Allah berkata ".....Allah mengharamkan jual beli dan mengharamkan riba". Riba juga bukan hanya sekedar penambahan karena jual beli juga ada penambahan.

Perbedaan antara bank syariah dan bank konvensional adalah terletak pada prinsip yang digunakan. Bank Syariah beroperasi menggunakan prinsip bagi hasil untuk menghindari riba, sedangkan bank konvensional menggunakan bunga dalam operasi dan berprinsip meraih untung yang sebesar-besarnya. Selain itu pada bank syariah terdapat Dewan Pengawas Syariah sedangkan pada bank konvensional tidak ada (Khasanah, 2009). Sebagai salah satu lembaga keuangan, bank perlu menjaga kinerja keuangan agar dapat beroperasi secara optimal. Terlebih lagi bank syariah harus bersaing dengan bank konvensional yang dominan dan telah berkembang 
Sadrinata, et al/Jurnal Ekonomi Syariah Teori dan Terapan Vol. 6 No. 10 Oktober 2019: 2095-2109; ANALISIS PERBANDINGAN PENGARUH VARIABEL MAKRO EKONOMI TERHADAP STABILITAS BANK SYARIAH DAN BANK KONVENSIONAL DI INDONESIA PERIODE TAHUN 2010-2017

pesat di Indonesia. Persaingan yang semakin tajam ini harus dibarengi dengan manajemen yang baik untuk bisa bertahan di industri perbankan. Salah satu faktor yang harus diperhatikan oleh bank untuk bisa terus bertahan hidup adalah kondisi keuangan bank (Rindawati, 2007).

Perkembangan perbankan syariah pada tahun 2015 s/d 2017 mengalami pertumbuhan signifikan. Perkembangan perbankan syariah dijelaskan pada tabel 1 :

Tabel 1.

Rasio Keuangan Bank Umum Syariah dan Unit Usaha Syariah Periode 2015-2017

\begin{tabular}{|l|c|c|c|}
\hline \multicolumn{1}{|c|}{ Keterangan } & 2015 & 2016 & 2017 \\
\hline CAR (\%) & 15,02 & 16,63 & 17,91 \\
\hline ROA (\%) & 0,49 & 0,63 & 0,63 \\
\hline NPF (\%) & 4,84 & 4,42 & 4,77 \\
\hline FDR (\%) & 88,03 & 85,99 & 79,65 \\
\hline BOPO (\%) & 97,01 & 96,22 & 94,91 \\
\hline
\end{tabular}

Sumber:www.bi.go.id

Pembiayaan bermasalah yang dihitung dengan rasio Non Performing Financing (NPF) dapat dijaga sesuai ketentuan Bank Indonesia yaitu dibawah $5 \%$. Kemampuan bank syariah dalam menghasilkan laba yang dihitung dengan rasio return on asset (ROA) mengalami fluktuatif selama periode tahun 2015 sampai dengan 2017. Pada saat itu bank umum syariah di Indonesia berjumlah 13 bank umum syariah.

\section{Rumusan Masalah}

Berdasarkan latar belakang masalah yang telah dipaparkan diatas maka permasalahan dalam penelitian ini dapat dirumuskan sebagai berikut :
1. Apakah variabel makro ekonomi yang terdiri dari Inflasi, GDP, Neraca Pembayaran, dan Suku Bunga BI berpengaruh secara parsial terhadap stabilitas bank syariah dan bank konvensional di Indonesia?

2. Apakah variabel makro ekonomi yang terdiri dari Inflasi, GDP, Neraca Pembayaran, dan Suku Bunga BI berpengaruh secara simultan terhadap stabilitas bank syariah dan bank konvensional di Indonesia?

3. Bagaimana perbedaan variabel makro ekonomi yang terdiri dari Inflasi, GDP, Neraca Pembayaran, dan Suku Bunga $\mathrm{BI}$ dalam mempengaruhi stabilitas perbankan antara bank syariah dan bank konvensional di Indonesia?

\section{Tujuan Penelitian}

Berdasarkan rumusan masalah diatas, maka tujuan penelitian adalah sebagai berikut:

1. Untuk menganalisis pengaruh secara parsial variabel makro ekonomi yang terdiri dari Inflasi, GDP, Neraca Pembayaran, dan Suku Bunga BI terhadap stabilitas bank syariah dan bank konvensional di Indonesia.

2. Untuk menganalisis pengaruh secara simultan variabel makro ekonomi yang terdiri dari Inflasi, GDP, Neraca Pembayaran, dan Suku Bunga BI terhadap stabilitas bank syariah dan bank konvensional di Indonesia.

3. Untuk menganalisis perbedaan variabel makro ekonomi yang terdiri dari Inflasi, GDP, Neraca Pembayaran, dan Suku 
Sadrinata, et al/Jurnal Ekonomi Syariah Teori dan Terapan Vol. 6 No. 10 Oktober 2019: 2095-2109;

ANALISIS PERBANDINGAN PENGARUH VARIABEL MAKRO EKONOMI TERHADAP STABILITAS BANK SYARIAH

DAN BANK KONVENSIONAL DI INDONESIA PERIODE TAHUN 2010-2017

Bunga $\mathrm{Bl}$ dalam mempengaruhi stabilitas perbankan antara bank syariah dan bank konvensional di Indonesia.

\section{LANDASAN TEORI}

Menurut Undang-Undang No. 21 Tahun 2008 tentang bank Syariah disebutkan bahwa Prinsip Syariah terdapat dua hal penting yaitu:

1. Prinsip syariah adalah prinsip hukum Islam, dan

2. Penetapan pihak/lembaga yang berwenang mengeluarkan fatwa yang menjadi dasar prinsip syariah.

Pasal 4 Undang-Undang No. 21 Tahun 2008 tentang bank Syariah dijelaskan bahwa Fungsi dari bank syariah, selain melakukan fungsi penghimpunan dan penyaluran dana masyarakat, juga melakukan fungsi sosial yaitu:

1. Dalam bentuk lembaga baitul maal yang menerima dana zakat, infak, sedekah, hibah dan lainnya untuk disalurkan ke organisasi pengelola zakat, dan

2. Dalam bentuk lembaga keuangan syariah penerima wakaf uang yang menerima wakaf vangdan menyalurkannya ke pengelola (nazhir) yang ditunjuk.

Pengertian bank menurut PSAK

Nomor 31 dalam Standar Akuntansi Keuangan adalah lembaga yang berperan sebagai perantara keuangan (financial intermediary) antara pihak yang memiliki dana dan pihak yang memerlukan dana, serta sebagai lembaga yang berfungsi memperlancar lalu lintas pembayaran. Falsafah yang mendasari kegiatan usaha bank adalah kepercayaan masyarakat. Hal tersebut tampak dalam kegiatan pokok bank yang menerima simpanan dari masyarakat dalam bentuk giro, tabungan, serta deposito berjangka dan memberikan kredit kepada pihak yang memerlukan dana.

Sedangkan Bank syariah adalah lembaga keuangan yang usaha pokoknya memberikan pembiayaan dan jasa-jasa lainnya dalam lalu lintas pembayaran serta peredaran vang yang pengoperasiannya disesuaikan dengan prinsip syariat Islam. Setiap lembaga keuangan syariah mempunyai falsafah mencari keridhoan Allah untuk memperoleh kebajikan di dunia dan di akhirat. Oleh karena itu menurut Antonio (2001:59) setiap kegiatan lembaga kevangan syariah harus:

1. Menjauhkan diri dari unsur riba, caranya:

a. Menghindari penggunaan sistem yang menetapkan di muka secara pasti keberhasilan suatu usaha. Sesuai dengan firman Allah SWT dalam Al-Qur'an Surat Luqman ayat 34:

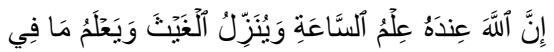

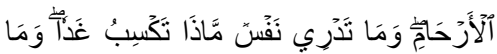

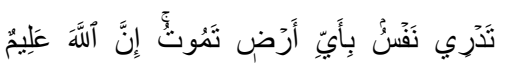

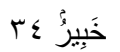

innāllāha 'indahū 'ilmūs-sā'ah, wa yunazzilul-gaīś, wa ya'lamu mā fil-arhām, wa mā tadrī nafsum māżā taksibu gadā, wa mā tadrī nafsum 
Sadrinata, et al/Jurnal Ekonomi Syariah Teori dan Terapan Vol. 6 No. 10 Oktober 2019: 2095-2109;

ANALISIS PERBANDINGAN PENGARUH VARIABEL MAKRO EKONOMI TERHADAP STABILITAS BANK SYARIAH

DAN BANK KONVENSIONAL DI INDONESIA PERIODE TAHUN 2010-2017

bi'ayyi arḍin tamūt, innāllāha 'alimun khabir

"Sesungguhnya Allah, hanya pada sisi-Nya sajalah pengetahuan tentang Hari Kiamat; dan Dialah Yang menurunkan hujan, dan mengetahui apa yang ada dalam rahim. Dan tiada seorangpun yang dapat mengetahui (dengan pasti) apa yang akan diusahakannya besok. Dan tiada seorangpun yang dapat mengetahui di bumi mana dia akan mati. Sesungguhnya Allah Maha Mengetahui lagi Maha Mengenal (Al-Qur'an kementrian agama RI, 2016:414)".

b. Menghindari penggunaan sistem prosentase untuk pembebanan biaya terhadap hutang atau pemberian imbalan terhadap simpanan yang mengandung unsur melipat gandakan secara otomatis hutang/simpanan tersebut hanya karena berjalannya waktu. Sesuai dengan firman Allah SWT dalam AlQur'an Surat Al-Imron ayat 130:

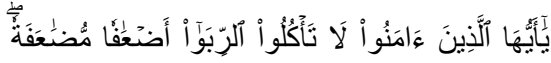

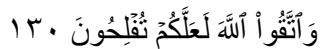

Yā ayyuhal-lazina āmanū lā ta'kulūrribā ad'afam-mudāa'afah wat-taqulLāha la'allakum tufliḥūn.

"Hai orang-orang yang beriman, janganlah kamu memakan riba dengan berlipat ganda] dan bertakwalah kamu kepada Allah supaya kamu mendapat keberuntungan

(Al-Qur'an kementrian agama RI, 2016:66)".

Menerapkan sistem bagi hasil dan perdagangan. Setiap transaksi kelembagaan syariah harus dilandasi atas dasar sistem bagi hasil dan perdagangan atau transaksinya didasari oleh adanya pertukaran antara vang dengan barang. Akibatnya pada kegiatan muamalah berlaku prinsip ada barang/jasa vang dengan barang, sehingga akan mendorong produk/jasa, mendorong kelancaran arus barang/jasa, dan dapat menghindari adanya penyalahgunaan kredit, spekulasi, dan inflasi.

\section{METODE PENELITIAN}

Pendekatan yang digunakan dalam penelitian ini adalah pendekatan kuantitatif dengan jenis penelitian yang digunakan adalah penelitian dokumenter. Penelitian dokumenter adalah penelitian yang data dan informasinya diperoleh dari bahan dokumentasi institusi (Supardi, 2005:34).

Setelah melakukan analisis tersebut, kemudian dilakukan analisis perbandingan pengaruh variabel makro ekonomi terhadap stabilitas banksyariah dan bank konvensional di Indonesia berdasarkan model uji bedadan analisis regresi linear berganda yang kemudian hasilnya bisa menunjukkan potensi stabilitas perbankan.

\section{Sumber Data}

Penelitian ini adalah penelitian kuantitatif, dengan objek penelitian adalah bank syariah dan 
Sadrinata, et al/Jurnal Ekonomi Syariah Teori dan Terapan Vol. 6 No. 10 Oktober 2019: 2095-2109; ANALISIS PERBANDINGAN PENGARUH VARIABEL MAKRO EKONOMI TERHADAP STABILITAS BANK SYARIAH DAN BANK KONVENSIONAL DI INDONESIA PERIODE TAHUN 2010-2017

bankkonvensional di Indonesia tahun 20102017. Data yang digunakan adalah data sekunder berupa laporan keuangan bank syariah dan bank konvensional. Dalam penelitian ini menggunakan data sekunder yaitu laporan keuangan tahunan bank syariah dan bank konvensional yang diambil dan dikutip dari data-data yang sudah ada kemudian diolah dan dianalisis. Data dalam penelitian ini diperoleh dari berbagai sumber seperti dari laporan bulanan Statistik Ekonomi Keuangan Indonesia (SEKI) Bank Indonesia, Statistik Perbankan Syariah (SPS) Otoritas Jasa Keuangan, Badan Pusat Statistik (BPS) dan beberapa sumber data yang dapat mendukung penelitian ini.

\section{Prosedur Pengumpulan Data}

Pengumpulan data dilakukan dengan metode dokumentasi. Metode pengumpulan dokumentasi adalah metode pengumpulan data yang dilakukan dengan cara menelaah catatan-catatan atau dokumen perusahaan sesuai dengan data yang diperlukan. Data yang diperlukan dalam penelitian ini adalah data sekunder yang berasal dari laporan keuangan tahunan bank syariah bank konvensional di Indonesia periode 2010-2017 yang diperoleh dari website masing-masing bank syariah, website OJK, website Bank Indonesia dan jurnal-jurnal baik media cetak maupun elektronik

\section{Populasi}

Menurut Anshori dan Iswati (2009:92) populasi adalah wilayah generalisasi yang terdiri atas subyek yang mempunyai kualitas dan karakteristik tertentu yang ditetapkan oleh peneliti untuk dipelajari dan kemudian ditarik kesimpulannya. Pada penelitian ini yang menjadi populasi adalah bank syariah dan bank konvensional di Indonesia yang ada pada periode 2010-2017.

\section{Sampel}

Teknik pengambilan sampel yang digunakan adalah purposive sampling. purposive sampling adalah teknik penentuan sampel berdasarkan kriteria yang ditetapkan sebelumnya (Sugiyono, 2002). Sampel yang digunakan adalah Bank Syariah dan bank konvensional di Indonesia yang diterbitkan oleh OJK, Statistik Bank Syariah dan Statistik Bank Konvensional di Indonesia yang ada pada periode 2010-2017.

Adapun kriteria sampel yang digunakan dalam penelitian ini adalah sebagai berikut:

1. Bank Umum Syariah dan Bank Umum Konvensional yang beroperasi di Indonesia selama periode pengamatan 2010-2017.

2. Bank Umum Syariah dan Bank Umum Konvensional yang bukan termasuk BPD, Bank Campuran maupun Bank Asing yang berkantor cabang di Indoneisa.

3. Bank Umum Syariah dan Bank Umum Konvensional yang memiliki variabelvariabel yang digunakan dalam penelitian.

4. Bank Umum Syariah dan Bank Umum Konvensional yang terdaftar di Otoritas 
Sadrinata, et al/Jurnal Ekonomi Syariah Teori dan Terapan Vol. 6 No. 10 Oktober 2019: 2095-2109; ANALISIS PERBANDINGAN PENGARUH VARIABEL MAKRO EKONOMI TERHADAP STABILITAS BANK SYARIAH DAN BANK KONVENSIONAL DI INDONESIA PERIODE TAHUN 2010-2017

Jasa Keuangan dengan kepemilikan total aset tertinggi.

Tabel 2.

Kerangka Sampel

\begin{tabular}{|l|l|c|}
\hline No. & \multicolumn{1}{|c|}{ Keterangan } & Jumlah \\
\hline Bank Syariah \\
\hline 1. & $\begin{array}{l}\text { Bank syariah yang } \\
\text { terdaftar di OJK }\end{array}$ & 13 \\
\hline 2. & $\begin{array}{l}\text { Bank syariah yang tidak } \\
\text { termasuk dalam kriteria } \\
\text { penelitian }\end{array}$ & $(2)$ \\
\hline 3. & $\begin{array}{l}\text { Bank syariah yang } \\
\text { memiliki variabel negatif } \\
\text { (rugi operasional) terkait } \\
\text { dengan } \\
\text { penelitian }\end{array}$ & $(4)$ \\
\hline \multicolumn{3}{|l|}{ variabel } \\
\hline 1. & $\begin{array}{l}\text { Bank Umumah BUS } \\
\text { yang terdaftar di OJK } \\
\text { dengan kepemilikan aset } \\
\text { tertinggi } \\
\text { menyesuaikan jumlah BUS }\end{array}$ & $\mathbf{7}$ \\
\hline Jumlah BUS dan BUK & $\mathbf{7 4}$ \\
\hline & $\begin{array}{l}\text { Laporan keuangan 2010- } \\
\text { 2017 }\end{array}$ & 7 \\
\hline & $\begin{array}{l}\text { Jumlah data Bank Umum } \\
\text { Syariah dan Bank Umum } \\
\text { Konvensional }\end{array}$ & 98 \\
\hline
\end{tabular}

Teknis Analisis dan Pengelolaan Data

Teknik analisis data dalam penelitian kuantitatif menggunakan analisis statistik.Analisis data dalam penelitian ini menggunakan dua tahap, yaitu satistik deskriptifdan statistik inferensial. Statistik deskriptif adalah metode mengatur, merangkum, danmempresentasikan data dengan cara informatif (Lind, 2013:6). Statistik deskriptif menyajikan nilai rata-rata (mean), niali terendah (minimum) dan nilai tertinggi (maximum) dari rasio-rasio yang diujikan yaitu variabel makroekonomi terdiri dari: Inflasi, GDP, Neraca Pembayaran, Nilai tukar rupiah, Suku Bunga Bl dan variabel stabilitas terdiri dari NPF yang dimiliki bank yang menjadi sampel selama periode 2010 hingga 2017. Statistik deskriptif pada penelitian ini menggunakan program Ms.Excel 2007.

Teknik statistik inferensial digunakan untuk menganalisis data sampel dan hasilnya diberlakukan atau digeneralisasikan untuk populasinya (Anshori dan Iswati, 2009:123). Dengan statistik inferensial, kita dapat menaksir (to estimate) dan menguji hipotesis (to test) populasi dengan melakukan perhitunganperhitungan untuk menemukan ukuranukuran sampel (Furqon, 2004:145).

Teknis analisis yang digunakan dalam penelitian ini adalah dengan menggunakan alat bantu berupa program SPSS.

\section{Persamaan Regresi}

Persamaan umum yang terbentuk dalam penelitian ini adalah sebagai berikut: NPF $=a+\beta_{1}$ INF $+\beta_{2}$ GDP $++\beta_{3} B C P+\beta_{4}$ RATE + e........... (3.4)

$N P L=a+\beta_{1}$ INF $+\beta_{2}$ GDP $++\beta_{3} B C P+\beta_{4}$ RATE + e........... (3.5)

di mana:

$\mathrm{NPF} \quad=$ Variabel $\mathrm{Y} 1$

$\mathrm{NPL} \quad=$ Variabel $\mathrm{Y} 2$

a $=$ konstanta

$\beta_{1} \ldots \beta_{4}=$ koefisien regresi variabel $\mathrm{X}$

Inf = Variabel Inflasi

GDP = Variabel GDP

$\mathrm{BCP}=$ Variabel Neraca pembayaran

RATE = Variabel Suku bunga BI

\section{Uji Asumsi Klasik}

Sebelum dilakukan pengujian terhadap hipotesis yang diajukan terlebih 
Sadrinata, et al/Jurnal Ekonomi Syariah Teori dan Terapan Vol. 6 No. 10 Oktober 2019: 2095-2109; ANALISIS PERBANDINGAN PENGARUH VARIABEL MAKRO EKONOMI TERHADAP STABILITAS BANK SYARIAH DAN BANK KONVENSIONAL DI INDONESIA PERIODE TAHUN 2010-2017

dahulu dilakukan uji asumsi klasik terhadap model regresi untuk mengetahui ada tidaknya penyimpangan data yang telah terkumpul (Ghozali, 2002). Adapun pengolahan data yang dilakukan nantinya dengan menggunakan alat bantu komputer dengan Program SPSS yang meliputi:

1. Uji Normalitas Data

Uji normalitas bertujuan untuk menguji apakah dalam model regresi variabel pengganggu atau residual memiliki distribusi normal (Ghozali, 2002). Cara mendeteksi apakah residual berdistribusi normal atau tidak, salah satunya dengan analisis grafik, yaitu dengan melihat normal probability plot dan uji KolmogorovSmirmov. Normal probability plot membandingkan distribusi kumulatif dengan distribusi normal.

a. Jika data menyebar di sekitar garis diagonal dan mengikuti arah garis diagonal, maka model regresi memenuhi asumsi normalitas.

b. Jika data menyebar jauh dari garis diagonal dan/ atau tidak mengikuti garis diagonal, maka model regresi tidak memenuhi asumsi normalitas.

Uji Kolmogorov-Smirmov digunakan juga untuk menguji normalitas residual, dasar analisinya adalah besarnya signifikan pada 0,5 maka disimpulkan nilai residual berdistribusi tidak normal dan berlaku sebaliknya.

2. Uji Multikolinearitas

Uji Multikolinearitas bertujuan untuk menguji apakah dalam model regresi ditemukan adanya korelasi antar variabel bebas (Ghozali, 2002). Model Regresi yang baik seharusnya tidak terjadi korelasi antara variabel independen. Untuk mendeteksi ada tidaknya multikolinearitas di dalam model regresi dapat dilihat dari nilai tolerance dan lawanya variance inflation factor (VIF). Nilai cutoff yang umum dipakai untuk menunjukkan adanya multikoloniearitas adalah nilai tolerance $\leq$ 0,10 atau sama dengan nilai $\mathrm{VIF} \geq 1$. Kedua ukuran ini menunjukkan setiap variabel independen manakah yang dijelaskan oleh variabel independen lainya.

3. Uji Heteroskedastisitas

Uji Heteroskesdastisitas brtujuan untuk menguji apakah dalam model regresi terjadi ketidaksamaan variance dari residual satu pengamatan ke pengamatan yang lain (Ghozali, 2002). Jika varians dari residual satu pengamatan ke pengamatan yang lain tetap, maka disebut homoskedastisitas dan jika berbeda disebut heteroskedastisitas. Uji statistik yang digunakan dalam penelitian ini dengan Uji Scatter Plot. Uji Scatter Plot dasar analisisnya adalah Jika tidak ada pola yang serta titik-titik yang menandakan komponen variabel menyebar diatas dan dibawah pada bidang scatter angka 0 pada sumbu $Y$, maka tidak terjadi heteroskedastisitas.

4. Uji Autokorelasi

Untuk melakukan uji autokorelasi, pada penelitian ini menggunakan besaran Durbin Watson, dimana ketentuannya adalah (Ghozali, 2002): 
Sadrinata, et al/Jurnal Ekonomi Syariah Teori dan Terapan Vol. 6 No. 10 Oktober 2019: 2095-2109; ANALISIS PERBANDINGAN PENGARUH VARIABEL MAKRO EKONOMI TERHADAP STABILITAS BANK SYARIAH DAN BANK KONVENSIONAL DI INDONESIA PERIODE TAHUN 2010-2017

a. Bila nilai DW terletak antara batas atas atau upper bound (du) dan (4du), maka koefisien autokorelasi sama dengan nol, berarti tidak ada autokorelasi.

b. Bila nilai DW lebih rendah daripada batas bawah atau lower bound (dl), maka koefisien autokorelasi lebih besar daripada nol, berarti ada autokorelasi positif.

c. Bila nilai DW lebih besar daripada (4dl), maka koefisien korelasi autokerelasi lebih kecil dari pada nol, berarti ada autokorelasi negatif.

d. Bila nilai DW terletak diantara batas atas (du) dan batas bawah (dl) atau DW terletak antara (4-du) dan (4-dl), maka hasilnya tidak dapat disimpulkan.

\section{Uji † (Pengujian Secara Parsial)}

Pada tahap ini akan dilakukan uji hipotesis guna menjawab rumusan masalah dan hipotesis yang diajukan dalam penelitian ini. Uji hipotesis yang digunakan dalam penelitian ini adalah menggunakan uji t. Uji $\dagger$ (test of significance individual parameter) untuk menguji pengaruh variabel bebas terhadap variabel terikat secara parsial, dimana dalam pengambilan keputusan dengan uji i ini adalah:

1. Jika nilai level of significance menurut hasil perhitungan lebih kecil dari pada 0,05, maka $\mathrm{H}_{0}$ ditolak dan $\mathrm{H}_{1}$ diterima. Artinya ada pengaruh secara parsial variabel bebas terhadap variabel terikat.

2. Jika nilai level of significance menurut hasil perhitungan lebih besar dari pada 0,05, maka $\mathrm{H}_{0}$ diterima dan $\mathrm{H}_{1}$ ditolak. Artinya, tidak ada pengaruh secara parsial variabel bebas terhadap variabel terikat.

\section{Uji F (Pengujian Secara Simultan)}

Uji F (Ftest) untuk menguji pengaruh variabel bebas terhadap variabel terikat secara simultan atau bersama-sama, dimana dalam pengambilan keputusan dengan uji $F$ ini adalah:

1. Jika nilai level of significance menurut hasil perhitungan lebih kecil dari pada 0,05, maka $\mathrm{H}_{0}$ ditolak dan $\mathrm{H}_{1}$ diterima. Artinya ada pengaruh secara simultan / bersamasama variabel bebas terhadap variabel terikat.

Jika nilai level of significance menurut hasil perhitungan lebih besar dari pada 0,05, maka $\mathrm{H}_{0}$ diterima dan $\mathrm{H}_{1}$ ditolak. Artinya, tidak ada pengaruh secara simultan / bersamasama variabel bebas terhadap variabel terikat.

\section{HASIL DAN PEMBAHASAN}

Pengaruh Inflasi terhadap NPF Bank Umum Syariah

Berdasarkan pada Tabel 4.10 bahwa nilai thitung variabel inflasi hasilnya adalah 0,151 dengan nilai signifikansi sebesar 0,890, berdasarkan hasil perhitungan tersebut, dimana nilai Sig. > 0,05, maka HO ditolak dan Hl diterima. Dengan demikian dapat disimpulkan bahwa Inflasi secara parsial tidak berpengaruh signifikan terhadap stabilitas bank syariah di Indonesia.

Bank umum syariah tidak terpengaruh dengan inflasi karena menerapkan sistem bagi hasil, sehingga 
Sadrinata, et al/Jurnal Ekonomi Syariah Teori dan Terapan Vol. 6 No. 10 Oktober 2019: 2095-2109; ANALISIS PERBANDINGAN PENGARUH VARIABEL MAKRO EKONOMI TERHADAP STABILITAS BANK SYARIAH DAN BANK KONVENSIONAL DI INDONESIA PERIODE TAHUN 2010-2017

inflasi tidak berpegaruh terhadap stabilitas bank umum syariah.

Hasil penelitian ini tidak sejalan dengan penelitian yang dilakukan oleh Lina (2013) menjelaskan bahwa variabel Inflasi, memberikan pengaruh negatif terhadap NPF. Hasil penelitian ini menunjukkan bahwa jika inflasi meningkat maka semakin menurunkan NPF. Didukung pendapat Adiwarman Karim (2007) kondisi negara yang mengalami inflasi tidak selalu diartikan, perekonomian mengalami penurunan. Analisa perbandingan perkembangan inflasi dengan pertumbuhan ekonomi. menunjukkan bahwa kenaikan inflasi yang diiringi dengan kenaikan pertumbuhan ekonomi menunjukkan bahwa meningkatnya pendapatan nasional sejalan dengan kenaikan harga barang dan jasa yang diproduksi suatu negara.

Pengaruh GDP terhadap NPF Bank Umum Syariah

Berdasarkan pada Tabel 4.10 bahwa nilai thitung variabel GDP hasilnya adalah 9,817 dengan nilai signifikansi sebesar 0,002, berdasarkan hasil perhitungan tersebut, dimana nilai Sig. < 0,05, maka HO diterima dan HI ditolak. Dengan demikian dapat disimpulkan bahwa GDP secara parsial berpengaruh positif dan signifikan terhadap stabilitas bank syariah di Indonesia.

GDP pada dasar nya adalah output barang dan jasa suatu negara dalam periode tertentu. Hubungan produk domestik bruto dengan neraca pembayaran adalah dengan peningkatan output barang dan jasa berarti peningkatan kapasitas produksi yang membuat stok barang menjadi melimpah. Dari limpahan barang inilah negara mengeskpor hasil produksinya keluar negeri guna memenuhi permintaan pasar. Dari hasil ekspor inilah devisa dihasilkan yang memperbaiki neraca pembayaran.

Pengaruh Neraca Pembayaran terhadap NPF Bank Umum Syariah

Berdasarkan pada Tabel 4.10 bahwa nilai thitung variabel Balance of Payments hasilnya adalah 1,408 dengan nilai signifikansi sebesar 0,254, berdasarkan hasil perhitungan tersebut, dimana nilai Sig. > 0,05, maka HO ditolak dan $\mathrm{Hl}$ diterima. Dengan demikian dapat disimpulkan bahwa Balance of Payments secara parsial tidak berpengaruh signifikan terhadap stabilitas bank syariah di Indonesia. Balance of payment (BOP) adalah suatu catatan yang disusun

Pengaruh Suku Bunga terhadap NPF Bank Umum Syariah

Berdasarkan pada Tabel 4.10 bahwa nilai thitung variabel $\mathrm{BI}$ Rate hasilnya adalah -0,348 dengan nilai signifikansi sebesar 0,751 , berdasarkan hasil perhitungan tersebut, dimana nilai Sig. > 0,05, maka $\mathrm{HO}$ ditolak dan $\mathrm{Hl}$ diterima. Dengan demikian dapat disimpulkan bahwa BI Rate secara parsial tidak berpengaruh signifikan terhadap stabilitas bank syariah di Indonesia. 
Sadrinata, et al/Jurnal Ekonomi Syariah Teori dan Terapan Vol. 6 No. 10 Oktober 2019: 2095-2109; ANALISIS PERBANDINGAN PENGARUH VARIABEL MAKRO EKONOMI TERHADAP STABILITAS BANK SYARIAH DAN BANK KONVENSIONAL DI INDONESIA PERIODE TAHUN 2010-2017

Bank umum syariah tidak terpengaruh dengan suku bunga karena menerapkan sistem bagi hasil, sehingga suku bunga tidak berpegaruh terhadap stabilitas bank umum syariah.

Hasil penelitian ini tidak sejalan dengan penelitian yang dilakukan oleh Ginting (2016) diperoleh hasil bahwa GDP memiliki pengaruh yang negatif terhadap NPL. Artinya jika semakin membaiknya perekonomian yang ditandai dengan semakin meningkatnya pertumbuhan ekonomi akan semakin mengurangi NPL dan memiliki pengaruh yang positif dengan variabel tingkat suku bunga pinjaman serta inflasi.

\section{Pengaruh Inflasi terhadap NPL Bank Umum}

\section{Konvensional}

Berdasarkan pada Tabel 4.11

bahwa nilai thitung variabel inflasi hasilnya adalah 6.536 dengan nilai signifikansi sebesar 0,007, berdasarkan hasil perhitungan tersebut, dimana nilai Sig. < 0,05, maka HO diterima dan Hl ditolak. Dengan demikian dapat disimpulkan bahwa Inflasi secara parsial berpengaruh positif dan signifikan terhadap stabilitas bank konvensional di Indonesia.

Tingkat inflasi yang tinggi dapat membawa konsekuensi pada kebijakan vang ketat (tight money policy), peningkatan suku bunga, dan peningkatan kredit bermasalah, yang akhirnya memicu kegagalan bank dan lembaga keuangan lainnya dalam sektor keuangan. Sebaliknya, gangguan pada sistem keuangan akan mempengaruhi efektivitas transmisi kebijakan moneter dan tingkat harga secara umum (Crockett, 1999).

\section{Pengaruh GDP terhadap NPL Bank Umum Konvensional}

Berdasarkan pada Tabel 4.11 bahwa nilai thitung variabel GDP hasilnya adalah 0,744 dengan nilai signifikansi sebesar 0,511, berdasarkan hasil perhitungan tersebut, dimana nilai Sig. > 0,05, maka HO ditolak dan HI diterima. Dengan demikian dapat disimpulkan bahwa GDP secara parsial tidak berpengaruh signifikan terhadap stabilitas bank konvensional di Indonesia.

Pengaruh Neraca Pembayaran terhadap NPL Bank Umum Konvensional

Berdasarkan pada Tabel 4.11 bahwa nilai thitung variabel Balance of Payments hasilnya adalah 1,368 dengan nilai signifikansi sebesar 0,265, berdasarkan hasil perhitungan tersebut, dimana nilai Sig. > 0,05, maka HO ditolak dan $\mathrm{Hl}$ diterima. Dengan demikian dapat disimpulkan bahwa Balance of Payments secara parsial tidak berpengaruh signifikan terhadap stabilitas bank konvensional di Indonesia.

Pengaruh Suku Bunga terhadap NPL Bank Umum Konvensional

Berdasarkan pada Tabel 4.11 bahwa nilai thitung variabel Bl Rate hasilnya adalah $-6,379$ dengan nilai signifikansi sebesar 0,008, berdasarkan hasil perhitungan tersebut, dimana nilai sig. > 0,05, maka $\mathrm{HO}$ ditolak dan $\mathrm{Hl}$ diterima. Dengan demikian dapat 
Sadrinata, et al/Jurnal Ekonomi Syariah Teori dan Terapan Vol. 6 No. 10 Oktober 2019: 2095-2109; ANALISIS PERBANDINGAN PENGARUH VARIABEL MAKRO EKONOMI TERHADAP STABILITAS BANK SYARIAH DAN BANK KONVENSIONAL DI INDONESIA PERIODE TAHUN 2010-2017

disimpulkan bahwa BI Rate secara parsial berpengaruh negatif dan signifikan terhadap stabilitas bank konvensional di Indonesia.

a. Perbedaan Variabel Makro Ekonomi Yang Terdiri Dari Inflasi, GDP, Neraca Pembayaran, dan Suku Bunga BI Dalam Mempengaruhi Stabilitas Perbankan Antara Bank Syariah Dan Bank Konvensional di Indonesia

Hasil penelitian menunjukkan bahwa terdapat perbedaan variabel makro ekonomi yang terdiri dari Inflasi, GDP, Neraca Pembayaran, dan Suku Bunga Bl dalam mempengaruhi stabilitas perbankan antara bank syariah dan bank konvensional di Indonesia.

Hasil penelitian ini mendukung penelitian yang dilakukan oleh Lina (2013), Ahmad dan Bashir (2013), Ginting (2016), Ali dan Iva Shingjergji (2013) serta Irum Saba, Rehana Kouser, dan Muhammad Azeem (2012) terdapat perbedaan variabel makro ekonomi yang terdiri dari Inflasi, GDP, Neraca Pembayaran, dan Suku Bunga $\mathrm{BI}$ dalam mempengaruhi stabilitas perbankan antara bank syariah dan bank konvensional di Indonesia

\section{SIMPULAN DAN SARAN}

Simpulan penelitian sebagai berikut:

1. Terdapat pengaruh secara parsial variabel makro ekonomi yang terdiri dari Inflasi, GDP, Neraca Pembayaran, dan Suku Bunga BI terhadap stabilitas bank syariah dan bank konvensional di
Indonesia. Terhadap stabilitas bank syariah, hanya variabel GDP yang berpengaruh signifikan terhadap stabilitas bank syariah di Indonesia. Terhadap stabilitas bank konvensional di Indonesia, hanya variabel inflasi dan suku bunga $\mathrm{BI}$ yang berpengaruh signifikan terhadap stabilitas bank konvensional di Indonesia.

2. Terdapat pengaruh secara simultan variabel makro ekonomi yang terdiri dari Inflasi, GDP, Neraca Pembayaran, dan Suku Bunga BI terhadap stabilitas bank syariah dan bank konvensional di Indonesia.

3. Terdapat perbedaan variabel makro ekonomi yang terdiri dari Inflasi, GDP, Neraca Pembayaran, dan Suku Bunga BI dalam mempengaruhi stabilitas perbankan antara bank syariah dan bank konvensional di Indonesia.

\section{SARAN}

1. Bagi penelitian selanjutnya

Penelitian selanjutnya dapat menggunakan variabel pendukung yang lain, seperti CAR, FBI, maupun faktor internal bank lainnya. Penelitian selanjutnya diharapkan mampu menggunakan metode lain untuk melakukan penelitian terhadap stabilitas perbankan antara bank syariah dan bank konvensional di Indonesia.

2. Bagi perusahaan atau praktisi lembaga kevangan

Seiring dengan adanya penelitian ini, perusahaan atau praktisi lembaga 
Sadrinata, et al/Jurnal Ekonomi Syariah Teori dan Terapan Vol. 6 No. 10 Oktober 2019: 2095-2109;

ANALISIS PERBANDINGAN PENGARUH VARIABEL MAKRO EKONOMI TERHADAP STABILITAS BANK SYARIAH

DAN BANK KONVENSIONAL DI INDONESIA PERIODE TAHUN 2010-2017

keuangan khususnya bank syariah dan bank konvensional diharapkan mampu meningkatkan kinerjanya. Selain itu bank syariah dan bank konvensional diharapkan dapat menjalankan kegiatan operasionalnya lebih optimal.

\section{DAFTAR PUSTAKA}

Al-Quran. 2014. Departemen Agama RI AlQuran Terjemah dan Tajwid. Jawa. Barat: Sygma.

Adiwarman Karim, 2010, Bank Islam: Analisis Fiqih dan Kevangan, Edisi Keempat, Jakarta: RajaGrafindo Persada.

Ascarya, 2008, How to Eradicate Inflation Under Dual Monetary System: The Case of Indonesia, paper has presented in 8th International Conference on Tawhidi Methodology Applied to Microenterprise Development. IEFTrisakti, Jakarta 78 January.

Blidisel, Rodica. G. et al, 2014, "Budgetary and Accounting Experience in Public Sector-Comparative Case Study", JEL codes: M41, H83.

Christophe Blot, Jérôme Creela, Paul Hubert, Fabien Labondance, Francesco Saraceno, 2015, Assessing the link between price and financial stability, Journal of Financial Stability 16 (2015) 71-88.

Crockett, Andrew, 1999, Why is Financial Stability a goal Of Public Policy?, Makalah, Federal Reserve Bank of Kansas City's Symposium, Maintaining Financial Stability in
Global Economy, Wyoming, 28-30 Agustus.

Halim Alamsyah, 2017, Menjaga Stabilitas Sistem Kevangan: Pengalaman Indonesia. Surabaya, 8 November 2017.

Hijriah, Almas, 2007, Pengaruh Faktor Fundamental Dan Risiko Sistematik Terhadap Harga Saham Properti Di Bursa Efek Jakarta, Sekolah Pascasarjana Universitas Sumatera Utara: Medan.

Hinza Siahaan, 2009, Manajemen Risiko Pada Perusahaan Dan Birokrasi, Jakarta: Elex Media Komputindo.

Iskandar, Syamsu, 2008, Bank dan Lembaga Kevangan Lainnya, Jakarta : PT. Semesta Asa Bersama.

Ismail, 2011, Manajemen Perbankan, Jakarta: Kencana.

Karl E Case dan Ray C Fair, 2002, PrinsipPrinsip Ekonomi Mikro. Jakarta: Pearson Education Asia.

Kurniawati. Erlin. 2009, Analisis Perbandingan Kinerja Keuangan Bank Syariah Dan Bank Konvensional Berdasarkan Rasio Keuangan, Skripsi Fakultas Ekonomi Universitas Muhammadiyah Purwokerto

Khan, Muhammad Akram. 1999, An Introduction to Islamic Economics. New Delhi: Kitab Bhavan.

Khasanah, Uswatun, 2009, Analisis Perbandingan Kinerja Keuangan Antara Bank Konvensional dan Bank 
Sadrinata, et al/Jurnal Ekonomi Syariah Teori dan Terapan Vol. 6 No. 10 Oktober 2019: 2095-2109;

ANALISIS PERBANDINGAN PENGARUH VARIABEL MAKRO EKONOMI TERHADAP STABILITAS BANK SYARIAH

DAN BANK KONVENSIONAL DI INDONESIA PERIODE TAHUN 2010-2017

Syariah. Skripsi. Universitas Muhammadiyah Surakarta.

Larionova, N., \& Varlamova, J, 2014, Correlation Analysis of Macroeconomic and Banking System Indicators. Procedia Economics and Finance, 14(14), 359-366.

https://doi.org/10.1016/S22125671(14)00724-2

LH.M. Ichwan Sam dkk, 2003, Himpunan Fatwa Dewan Syari'ah Nasional, Jakarta: P.T. Intermasa.

M. Nur Rianto Al Arif, 2010, Teori Makroekonomi Islam, Jakarta: Alfabeta.

Muhammad Syafii Antonio, 2001, Bank Syariah dari Teori ke Praktik. Jakarta: Gema Insani.

Muhammad Quraish Shihab, 2010, AlQur'an dan Maknanya, Pisangan: Lentera Hati.

Nurul Huda, 2008, Ekonomi Makro Islam: Pendekatan Teoritis, Jakarta: Kencana.

Nazir. 1983. Metode Penelitian, Jakarta: Ghalia Indonesia

Nopirin, 2008, Pengantar IImu Ekonomi Makro \& Mikro, Edisi Pertama, BPFE: Yogyakarta

Pangemanan, Vanessa, 2013, Inflasi, Nilai Tukar, Suku Bunga Terhadap Risiko Sistematis Pada Perusahaan SubSektor Food And Beverage Di BEI. Fakultas Ekonomi dan Bisnis, Jurusan Manajemen Universitas Sam Ratulangi: Manado.
Pratama Rahardja dan Mandala Manurung, 2004, Pengantar Makroekonomi, Jakarta: LPFE-UI.

Rindawati, Ema, 2007, Analisis Perbandingan Kinerja Keuangan Antara Perbankan Syariah dan Perbankan Konvensional. Skripsi. Universitas Islam Indonesia.

Rivai, Veithzal dan Arviyan Arifin, 2010,Islamic Banking: Sebuah Teori, Konsep, dan Aplikasi. Jakarta: Bumi Aksara

Sadono Sukirno, 2000, Makroekonomi Modern: Perkembangan Pemikiran dari Klasik Hingga Keynesian Baru, Jakarta: Raja Grafindo Persada.

Sadono Sukirno, 2007, Makroekonomi Modern, Jakarta: Raja Grafindo Persada.

Sadono Sukirno, 2010, Makroekonomi Suatu Pengantar, Jakarta: Rajawali Pers.

Surifah, 2002, Kinerja Keuangan Perbankan Swasta Nasional Indonesia Sebelum dan Setelah Krisis Ekonomi. Jurnal Akuntansi JAAI Volume 6 No. 2 Desember 2002.

Suharno Eliandy, 2017, Peran Dan Fungsi LPSDalam Menjaga StabilitasSistem Keuangan Indonesia, Disampaikan pada acara Training of Trainers (ToT)Di Fakultas Ekonomi dan Bisnis Universitas Airlangga, Surabaya, 9 November 2017.

Tambunan, Tulus, 2012, Usaha Mikro Kecil dan Menengah di Indonesia : isu-isu penting, Jakarta : LP3ES. 
Sadrinata, et al/Jurnal Ekonomi Syariah Teori dan Terapan Vol. 6 No. 10 Oktober 2019: 2095-2109;

ANALISIS PERBANDINGAN PENGARUH VARIABEL MAKRO EKONOMI TERHADAP STABILITAS BANK SYARIAH

DAN BANK KONVENSIONAL DI INDONESIA PERIODE TAHUN 2010-2017

Tampubolon, Robert, 2006, Risk Manajemen

(Manajemen Risiko): Pendekatan

Kualitatif Untuk Bank Komersial,

Jakarta : PT. Elex Media

Komputindo.

Tri K Pracoyo dan Antyo, 2007, Aspek Dasar

Ekonomi Makro di Indonesia Seri

Pertama, Jakarta: Grasindo.

Zainudin. 2010. Hukum Perbankan Syariah.

Jakarta: Sinar Grafika.

Peraturan Perundang-undangan:

Undang-Undang No. 21 Tahun 2008 tentang Perbankan Syariah

$\mathrm{PBI}$

$$
\text { No.10/16/PBI/2007 tentang }
$$

Pelaksanaan Prinsip Syariah Dalam Kegiatan Penghimpunan Dana Dan Penyaluran Dana Serta Pelayanan Jasa Bank Syariah.

PBI No.10/17/PBI/2008 tentang Produk Bank Syariah Dan Unit Usaha Syariah.

PBI No.10/18/PBI/2008 tentang Rekonstruksi Pembiayaan Bagi Bank Syariah.

PBI No.10/23/PBI/2008 tentang perubahan kedua atas PBI No.6/21/PBI/2004 tentang Giro Wajib Minimum Dalam Rupiah Dan Valuta Asing Bagi Bank Umum Yang Melaksanaan Kegiatan Usaha Berdasarkan Prinsip Syariah.

PBI No.10/24/PBI/2008 tentang perubahan kedua atas PBI No.8/21/PBI/2008 tentang Penilaian Kualitas Aktiva Bank Umum Yang Melaksanakan Kegiatan Usaha Berdasarkan Prinsip Syariah.

PBI No.10/32/PBI/2008 tentang Komite Perbankan Syariah.
PBI No.11/3/PBI/2009 Tentang Bank Umum Syariah 